\title{
$\gamma$-Radiolysis of Saturated Fatty Acids and Esters in Liquid State
}

\author{
Kazuta Kitahara, Yoshitaka KUgA, \\ Kumiko HaradA, and Atsushi SUgII \\ Faculty of Pharmaceutical Sciences, Kumamoto \\ University, Oe-honmachi, Kumamoto-shi \\ Received October 18, 1975
}

\begin{abstract}
In order to elucidate the relation between radiolysis and chain length of the materials, $r$-radiolysis of three series of the saturated carboxylic acids, their methyl esters and dicarboxylic acid dimethyl esters has been studied in a liquid state. It was found that unreacted fractions of materials $(Y)$ decrease exponentially with an increase in chain length $(n)$ in each series. Variation of $G(-M)$ with carbon numbers was also discussed.
\end{abstract}

\section{Introduction}

In view of many proposals to irradiate lipid-containing foods, it is important to investigate the behavior of model system with irradiation in terms of simplification of the complicated reaction mechanism under $\gamma$-irradiation. Many radiation chemical investigations on the fatty acids and related compounds bave been presented. Whitehead, et al. ${ }^{1)}$ reported that the decarboxylation of fatty acids with $\alpha$-particle irradiation decreases as the size of molecule increases from $\mathrm{C}_{2}$ to $\mathrm{C}_{22}$. It has been also shown that the yields of carbon dioxide $G\left(\mathrm{CO}_{2}\right)$ with $\gamma$-irradiation decrease with the chain length of normal saturated fatty acids by Johnsen ${ }^{2)}$ and Jones ${ }^{3)}$. Moreover, Wu and Howton ${ }^{4)}$ have reported that $G$ values of hydrocarbons resulting from ${ }^{60} \mathrm{Co}$ $\gamma$-irradiation of fatty acids are in agreement with $G\left(\mathrm{CO}_{2}\right)$ obtained by Jones ${ }^{3)}$. On the other hand, relatively few studies ${ }^{5)}$ ?) on the radiolysis of fatty acid esters are presented. Most of the studies, however, have been focussed on the decarboxylation or the analysis of radiolysis products.

In this study, in order to elucidate interdependence of radiolytic behavior on the chain length of materials, three series of the normal saturated fatty acids, their monomethyl esters and aliphatic dicarboxylic acid dimethyl esters were irradiated in a liquid state with ${ }^{\epsilon_{0}} \mathrm{Co} \gamma$-rays at an ambient temperature.

\section{Fxperimental}

\subsection{Materials}

Dimethyl glutarate, dimethyl pimelated, imethyl suberate and dimethyl azelate were prepared by esterification of the corresponding dicarboxylic acids, and other materials were purchased from Wako Pure Chemical Ind. and Tokyo Kasei Co. Purity of all the reagents was checked by gas chromatography and found to be more than $98 \%$ except for methyl pelargonate (95\%).

\section{$2 \cdot 2$ Irradiation}

Samples $(0.2 \mathrm{~g})$ were purged by bubbling nitrogen and irradiated in a small glass ampoule with $\gamma$-rays $\left(45 \mathrm{kCi}-{ }^{60} \mathrm{Co}\right)$ at an ambient temperature.

\subsection{Analysis}

Gas chromatography was carried out on a Shimadzu GC-4BMPF equipped with dual flame ionization detectors. Glass columns $(3 \mathrm{~mm} \times 3 \mathrm{~m})$ packed with $25 \%$ diethylene glycol succinate on 60-80 mesh Chromosorb $\mathrm{W}$ were used for the methyl esters, and columns packed with $10 \%$ FAL-M on $60-80$ mesh Shimalite for the free acids. 


\section{Results and Discussion}

3.1 The relation between unreacted fraction and chain length

Unreacted fractions of materials were calculated from the peak area of gas chromatogram. The logarithms of these fractions, $Y$, were found to decrease linearly with chain length $(n)$ of fatty acids and their methyl esters, as shown in Fig. 1.

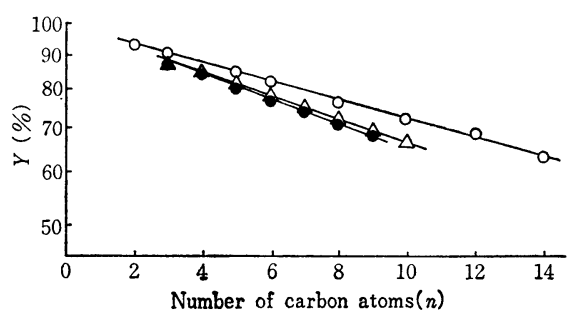

Fig. 1 The relation between unreacted fractions of materials and chain length. Total dose: $2 \times 10^{8} \mathrm{rad}$

$\bigcirc$ : normal aliphatic carboxylic acid methyl ester

$\triangle$ : dicarboxylic acid dimethyl ester

: normal aliphatic carboxylic acid

Accordingly, $Y$ can be expressed as

$$
Y=100 e^{-k n}
$$

where $n$ is a number of carbon atom (except for ester substituent group) and $k$ is a constant associated with total doses and a kind of materials. This result indicates that $Y$ is predictable provided the values of $k$ and $n$ are known.

The values of $k$ were obtained at a total dose of $2 \times 10^{8}$ rad with monocarboxylic acid methyl ester (I), dicarboxylic acid dimethyl ester (II) and monocarboxylic acid (III) to be $0.0326,0.0408$ and 0.0420 , respectively. The higher the $k$-value, the more sensitive to irradiation. The values of $k$ are in the order, III $>$ II $>$ I, i.e., free acids are more sensitive than their esters.

The difference of $k$ values between free acids and esters may be attributed to the reactivity of two radicals, $\mathrm{H} \cdot$ and $\mathrm{CH}_{3} \cdot$, which are produced by irradiation as shown in Scheme $\mathbf{1}^{\text {s) }}$.

The high reactivity of the radicals leads

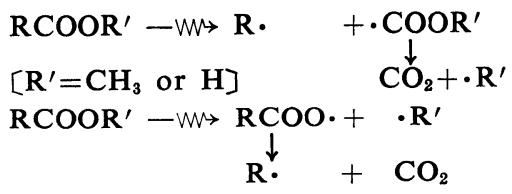

Scheme 1

to the degradation of parent molecules as a result of interaction with them. It is well known that $\mathbf{H}$. is more reactive than $\mathrm{CH}_{3} \cdot$.

\subsection{The dependence of the value $(k)$ on total doses}

The values of $k$ for (I) were determined over the range of total doses $1-3 \times 10^{8}$ rad. As is shown in Fig. 2, a log-log plot of $k$ vs. total dose is linear, then

$$
k=A D^{m}
$$

$A$ and $m$ are constants of material irradiated. From the experimental results for series (I), the values of $A$ and $m$ are 0.0192 and 0.75, respectively. Equation (2), therefore, is expressed as

$$
k=0.0192 D^{0.75}
$$

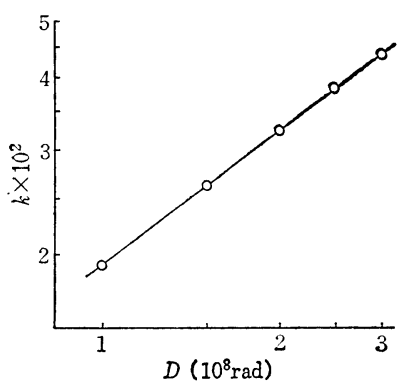

Fig. 2 Dependence of $k$ on total dose (D) for normal aliphatic carboxylic acid methyl esters.

The value of $k$ can be calculated numerically from the value of $D$ by the use of Eq. (3). These equations suggest that the rate of degradation of materials within a homologcus series in a liquid state may be estimated in the case of different doses on the basis of a simple calculation.

\subsection{Consideration of $G$ value}

The numbers of molecules permanently transformed per $100 \mathrm{eV}$ of energy absorbed, $G(-\mathrm{M})$, are plotted against $n$ in Fig. 3 . 


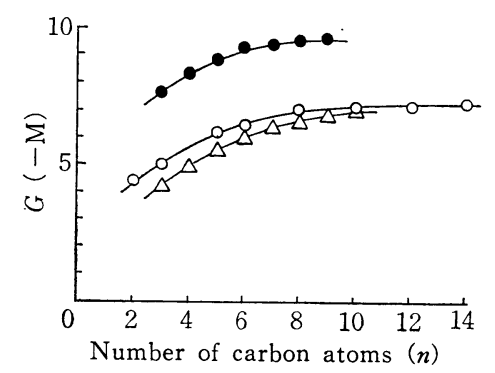

Fig. 3 Variation of $G(-\mathrm{M})$ with $n$. Symbols are the same as in Fig.1

Although $Y$-values for dimethyl ester (II) are lower than those for monomethyl ester (I) of the same chain length (Fig. 1), G(M) values for (II) are lower than those for (I) (Fig. 3). This may be explained from the difference of their structures. For dimethyl esters have two carboxyl groups which are more sensitive to $\gamma$-irradiation, while molecular weight of (II) are higher than those of (I) with the same $n$.

Three $G(-\mathrm{M})$ curves shown in Fig. 3 gradually increase with an increase in $n$, and each curve seems to have a tendency to approach a definite value. It is due to the decrease of number of total carboxyl groups (or molecule) per gram with an increase in $n$ (or molecular weight). The

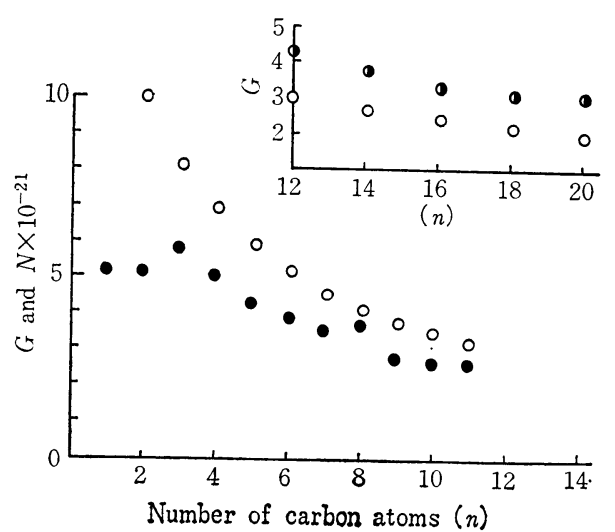

Fig. 4 Variation of the number of molecules per gram, $G\left(\mathrm{CO}_{2}\right)$ and $G(\mathrm{RH})$ of normal aliphatic carboxylic acids vs. $n$.

$\bigcirc$ : number of molecules per gram $(N)$

: $G\left(\mathrm{CO}_{2}\right)$ by Jones

(D) $G(\mathrm{RH})$ by Wu, et al. (solid state) number of molecules per gram of materials against $n$ is presented in Fig. 4 .

It is found that the shape of this curve is very similar to those of $G\left(\mathrm{CO}_{2}\right)$ and $G$ $(\mathrm{RH})$ curves shown by Jones ${ }^{3)}$ and $\mathrm{Wu}$, et $\mathrm{al}^{4)}$. It is suggested that one of the reason for decreasing curve of $G\left(\mathrm{CO}_{2}\right)$ and $G(\mathrm{RH})$ is related to the decrease of number of molecules in constant quantity of materials with increase of $n$.

Schuler and Kuntz ${ }^{8)}$ have reported a relationship between $n$ and the amounts of $\mathrm{CH}_{3}$. produced from normal saturated hydrocarbons by $\gamma$-irradiation; the yield of $\mathrm{CH}_{3}$. is given by

$$
G\left(\mathrm{CH}_{3} \cdot\right)=\frac{2.04}{(n-1)^{2}}
$$

Little attention has also been given to the conception of total number of molecules in their discussion.

\section{Acknowledgment}

This study was supported in part by the National Universities Program for the Common Use of JAERI Facilities.

\section{References}

1) W.L. Whitehead, G. Goodman and I.A. Breger: J. Chim. Phys., 48, 184 (1951); Chem. Abst., 45, 9389 (1951).

2) R.H. Johnsen: J. Phys. Chem., 63, 2041 (1959)

3) A.R. Jones: Radiat. Res., 47, 35(1971); 48, 447 (1971); 50, 41 (1972)

4) G. Wu and D.R. Howton: Radiat. Res., 57, 390 (1974)

5) J.J. Macfarlane and J.W. Sweeting: Radiat. Res., 42, 50 (1970)

6) R.W. Hummel: Trans. Faraday Soc., 56, 234 (1960)

7) J.J. Macfarlane and J.W. Sweeting: Nature, 207, 520 (1965)

8) R.H. Schuler and R.R. Kuntz: J. Phys. Chem., 67, 1004 (1963) 
要 旨

\section{飽和脂肪酸およびエステルの放射線分解}

北原一太，久我義隆，原田久美子，杉井 篤

熊本大学薬学部 熊本市大江本町 $5-1$

室温において液状の 飽和脂肪酸, エステルおよび二塩基性脂肪酸エステルについて, 大線量の ${ }^{60} \mathrm{Co}-\gamma$ 線を照射した場合の炭素数と放射線分解の関係をしらべた。

その結果, 残存パーセントの対数と各脂肪酸の炭素数との間には直線関係が成立することがわか った。さらに照射線量との関係， $G(-\mathrm{M})$ と炭素数についても検討した。 